\title{
The Association of Serum Vitamin D Deficiency and Metabolic Risk Factors in Chinese Adults with Prediabetes: A Cross-Sectional Study
}

\author{
Li-Qiang Tian ${ }^{1}$, Wen-Qi SHI ${ }^{2}$, Yang ZHOU ${ }^{2}$, Yu-Wen ZHANG ${ }^{3}$ and Mei-Lin ZHANG ${ }^{2}$ ** \\ ${ }^{1}$ Department of Clinical Laboratory, Tianjin Chest Hospital, Tianjin 300222, China \\ ${ }^{2}$ Department of Nutrition and Food Science, School of Public Health, Tianjin Medical University, \\ Tianjin 300070, China \\ ${ }^{3}$ Health Education and Guidance Center of Heping District, Tianjin 300021, China
}

(Received November 28, 2018)

\begin{abstract}
Summary The association of serum vitamin D deficiency and metabolic risk factors in Chinese adults with prediabetes (PreDM) has not been investigated. The present study aimed to investigate the association of serum vitamin D deficiency and metabolic risk factors in Chinese adults with PreDM. In this cross-sectional study, we stratified 412 PreDM patients into vitamin D sufficient, vitamin D insufficient and vitamin D deficient subgroups. The physical examination data was collected. Serum 25-hydroxyvitamin $\mathrm{D}_{3}\left[25(\mathrm{OH}) \mathrm{D}_{3}\right]$ were measured by high performance liquid chromatography. The prevalence of vitamin D deficiency and insufficiency in PreDM patients were $30.58 \%$ and $26.70 \%$, respectively. Compared with the vitamin D deficient group, the prevalence of metabolic syndrome, central obesity, hyperglycemia and hypertension were higher than those in the vitamin $\mathrm{D}$ insufficient or sufficient group $(p<0.05)$. Moreover, the prevalence of dyslipidemia in the vitamin D deficient group was higher than those in the vitamin D sufficient group $(p<0.05)$. We observed an inverse relationship between $25(\mathrm{OH}) \mathrm{D}_{3}$ levels and waist circumference, triglyceride, and serum uric acid $(\beta=-0.315 ; \beta=-0.134 ; \beta=-0.239)$, a positive relationship between $25(\mathrm{OH}) \mathrm{D}_{3}$ levels and high-density lipoprotein cholesterol $(\beta=0.197)$ after adjusting for age, sex and body mass index. Vitamin D deficiency is very common among PreDM patients in China and this deficiency is related to metabolic risk factors.
\end{abstract}

Key Words 25-hydroxyvitamin $\mathrm{D}_{3}$, waist circumference, triglyceride, uric acid, highdensity lipoprotein cholesterol

The prevalence of type 2 diabetes (T2DM) has increased significantly in recent decades in China (1). The most recent national survey in 2010 reported that the prevalence of diabetes was $11.6 \%$, representing an estimated 113.9 million adults in China with diabetes (2). Two clinical constructs for identifying individuals at high risk of developing T2DM are prediabetes (PreDM) and metabolic syndrome (MS). MS is a cause of non-communicable diseases (NCDs), such as T2DM and cardiovascular disease (CVD) (3). The incidence of MS differs among nations or races according to the socio-cultural background and economic level, and it has been showing an increasing trend. A survey of the prevalence of MS of 98,042 Chinese aged $18 \mathrm{y}$ and older utilizing the 2010-2012 China National Nutrition and Health Survey (CNNHS), revealed an incidence of $24.2 \%$ (4). According to the 2010 survey, the prevalence of PreDM was $50.1 \%$ in China (2), implying that approximately 500 million Chinese adults may have had PreDM. The incidence of T2DM from PreDM is about $10 \%(5.8-13.2 \%)$ per year (5-8). Therefore, the health management of subjects with PreDM is important for the effective management of NCDs.

\footnotetext{
*To whom correspondence should be addressed.
}

E-mail: zhangmeilin@tmu.edu.cn
Vitamin D deficiency which is defined as a serum 25-hydroxyvitamin $\mathrm{D}_{3}\left[25(\mathrm{OH}) \mathrm{D}_{3}\right]$ level of less than $20 \mathrm{ng} / \mathrm{mL}$, has been termed a "worldwide public health issue" (9). In China, there have been some studies on vitamin D status in the metropolitan cities of China, such as Beijing (10, 11), Shanghai (12) and Tianjin (13), and vitamin D deficiency/insufficiency, which was found to be highly prevalent. Tianjin is a municipality and the economic center in the Bohai rim region, which is located in the northern part of China, at a latitude of $39^{\circ} \mathrm{N}$. The ultraviolet radiation is of a lower intensity than that in lower latitude areas. Moreover, the rapid industrialization of northern China has led to severe air pollution, with consequently decreased penetration of ultraviolet radiation from the sun (14). There was a high prevalence of vitamin D deficiency/insufficiency among urban and rural Han Chinese residents in Tianjin. There were $52.31 \%$ of participants who did not achieve the optimal serum vitamin D level, only $47.63 \%$ of participants achieved the optimal level (13).

Traditionally, vitamin D serves as an important factor for bone health and mineral metabolism (15). Recently, it has been reported that vitamin D might have additional metabolic effects on tissues other than bone and calcium metabolism (16-18). Some epidemiologic evidence have suggested that low serum $25(\mathrm{OH}) \mathrm{D}_{3}$ levels 
were also deemed to be related to the metabolic risk factors (19). Some US studies have reported that the importance of initial management in the prevention of MS as well as CVD in PreDM adults $(20,21)$. And vitamin D might have a protective role in the underlying disorders of PreDM $(22,23)$. To our knowledge, there have been several studies reported the positive relationship between vitamin D deficiency and MS and its components among adults with non-diabetic adults $(24,25)$ or patients with diabetes (26). Although there was only one study has examined the association between serum vitamin D levels and metabolic risk factors among adults with PreDM in Korean (27), the result could not be directly applied to a Chinese population due to ethnic differences in vitamin D metabolism and its nutritional status (28). Thus, we aimed to explore the nature and strength of the relationship between serum vitamin D status and metabolic risk factors among Chinese adults with PreDM.

\section{MATERIALS AND METHODS}

Population. A total of 1,115 subjects aged $20-70 \mathrm{y}$ were performed routine health check-up in Health Education and Guidance Center of Heping District, Tianjin, China during November to December in 2015, were enrolled. Participants with fasting plasma glucose (FPG) concentration of $110-126 \mathrm{mg} / \mathrm{dL} \quad(6.1-7.0 \mathrm{mmol} / \mathrm{L})$ were classified as PreDM (29), those with a glucose concentration $<110 \mathrm{mg} / \mathrm{dL}(<6.1 \mathrm{mmol} / \mathrm{L})$ or $\geq 126 \mathrm{mg} /$ $\mathrm{dL}(7.0 \mathrm{mmol} / \mathrm{L})$ or self-reported current diabetes treatments were excluded. Subjects with incomplete data and vitamin D supplement were excluded. The final crosssectional study population comprised 412 subjects.

The study protocol was approved by the Ethics Committee of Tianjin Medical University (TMUhMEC 20120110), and it was in compliance with the declaration of Helsinki. Written informed consent was obtained from all participates.

Data collection. Height was measured without shoes to the nearest $1 \mathrm{~cm}$ and weight measured in light clothing to the nearest $0.1 \mathrm{~kg}$ on a beam balance scale. Body mass index (BMI) was calculated as weight in kilograms divided by the square of the height in meters $\left(\mathrm{kg} / \mathrm{m}^{2}\right)$. Waist circumference (WC) was measured with an inelastic tape to the nearest $0.1 \mathrm{~cm}$ at a midpoint between the lowest rib and the iliac crest. Two measurements of blood pressure were taken using a standardized mercury sphygmomanometer on the right arm, after a 15-min rest in a sitting position; the average of the two measurements was used as subject blood pressure. Venous blood samples were taken from all participants after an overnight fast (12 h at least) and the samples were stored at $-80^{\circ} \mathrm{C}$ until assessment assayed performed. Serum total cholesterol (TC), triglyceride (TG), high-density lipoprotein cholesterol (HDL-C), and low-density lipoprotein cholesterol (LDL-C) were estimated by enzyme method with commerial assay kit from the Sichuan Marker Biotechnology Co., Ltd. (Chengdu, China). Serum uric acid (SUA), FPG and serum lipid profiles were determined by automatic biochemical analyzer (Hitachi-7180, Tokyo, Japan).
Information about demographic characteristics and lifestyle habits, including smoking, drinking and physical activity, were collected by trained interviewers. Current smokers were defined as those who smoked at least one cigarette per day and non-smokers were defined as those who were either former smokers or never smoked a cigarette in their lives. Those who stopped smoking for less than a year were classified as smokers. A participant was classified as "drinker" in case of having drunk beer or any other alcoholic beverage during the last year. Physical activity was recorded as a three level variable (light, moderate, and heavy), as recommended by the China Nutrition Society. The current time spent outdoors $(\mathrm{h} / \mathrm{d})$ and sunshine time $(\mathrm{h} / \mathrm{d})$ also documented the frequency and mean duration of daytime outdoor activity. Serum $25(\mathrm{OH}) \mathrm{D}_{3}$ levels were determined using high-performance liquid chromatography (HPLC).

Definition of terms. On the basis of the criteria of the American Diabetes Association, individuals with $110 \mathrm{mg} / \mathrm{dL}(6.1 \mathrm{mmol} / \mathrm{L}) \leq \mathrm{FPG}<126 \mathrm{mg} / \mathrm{dL}(7.0$ $\mathrm{mmol} / \mathrm{L}$ ) were classified as PreDM (29). Vitamin D status was defined as follows: A serum level of $25(\mathrm{OH}) \mathrm{D}_{3}$ $<20 \mathrm{ng} / \mathrm{mL}$ was considered to be vitamin D deficiency, whereas a level 20-30 ng/mL was vitamin D insufficiency, and to maximize vitamin D's effect for health (vitamin D sufficiency), 25(OH)D $\mathrm{D}_{3}$ should be $\geq 30 \mathrm{ng} /$ $\mathrm{mL}(30)$.

The International Diabetes Federation (IDF) criteria (31) was used to define MS in the present study because this definition considers the ethnic difference for central obesity. According to the IDF criteria, participants were classified as having MS if they had central obesity (WC $\geq 90 \mathrm{~cm}$ for men and $\geq 80 \mathrm{~cm}$ for women) plus any other two abnormalities of those shown below: (1) Hypertension: systolic blood pressure (SBP) $\geq 130 \mathrm{mmHg}$, or diastolic blood pressure (DBP) $\geq 85 \mathrm{mmHg}$, or treatment of previously diagnosed hypertension; (2) Hypertriglyceridemia: TG $>150 \mathrm{mg} / \mathrm{dL}$ or specific medical treatment for this lipid abnormality; (3) Low HDL-C: HDL$\mathrm{C}<40 \mathrm{mg} / \mathrm{dL}$ for men or $<50 \mathrm{mg} / \mathrm{dL}$ for women; (4) Hyperglycemia: $\mathrm{FPG} \geq 100 \mathrm{mg} / \mathrm{dL}$ or treatment of previously diagnosed diabetes. Dyslipidemia was defined as having hypertriglyceridemia or low HDL-C.

Statistical analysis. Statistical analysis was performed with the SPSS 16.0 software (SPSS, Chicago). Means \pm SD were used as descriptive statistics for normally distributed variables. All quantitative variables were tested for normality distribution using the Kolmogorov-Smirnov test and continuous parameters with a non-normal distribution were logarithmically transformed before being used in the subsequent parametric procedures. For continuous variables, the analysis of variance (ANOVA) test with Bonferonni post hoc comparison was used for between-group comparisons of normally distributed. Comparative analyses of categorical variables were carried out using a Chi-square test. Multiple linear regression analysis was used to demonstrate a linear relationship between serum $25(\mathrm{OH}) \mathrm{D}_{3}$ levels and metabolic risk factors. The covariates for the adjusted $\beta$ included age, sex and BMI. For all these anal- 
Table 1. General characteristics of prediabetic patients by vitamin D status.

\begin{tabular}{|c|c|c|c|c|c|}
\hline \multirow[b]{2}{*}{ Characteristics } & \multicolumn{4}{|c|}{ Vitamin D status } & \multirow[b]{2}{*}{$p$ value } \\
\hline & Total & $\begin{array}{c}\text { Vitamin D } \\
\text { deficiency } \\
(<20 \mathrm{ng} / \mathrm{mL})\end{array}$ & $\begin{array}{c}\text { Vitamin D } \\
\text { insufficiency } \\
(20 \text { to }<30 \mathrm{ng} / \mathrm{mL})\end{array}$ & $\begin{array}{c}\text { Vitamin D } \\
\text { sufficiency } \\
(\geq 30 \mathrm{ng} / \mathrm{mL})\end{array}$ & \\
\hline Number of subjects & 412 & 126 & 110 & 176 & \\
\hline Male (\%) & $96(23.30)$ & $41(32.54)$ & $19(17.27)$ & $36(20.45)$ & 0.016 \\
\hline Age $(y)$ & $48.49 \pm 11.47$ & $49.75 \pm 10.47$ & $48.73 \pm 10.87$ & $47.43 \pm 12.44$ & 0.215 \\
\hline Smoking (\%) & & & & & 0.301 \\
\hline Never & $376(91.26)$ & $113(89.68)$ & $98(89.09)$ & $165(93.75)$ & \\
\hline Current & $36(8.74)$ & $13(10.32)$ & $12(10.91)$ & $11(6.25)$ & \\
\hline Drinking alcohol (\%) & & & & & 0.998 \\
\hline Daily & $10(2.43)$ & $2(1.59)$ & $6(5.45)$ & $2(1.14)$ & \\
\hline Occasionally & $172(41.75)$ & $55(43.65)$ & $39(35.45)$ & $78(44.31)$ & \\
\hline Never & $230(55.82)$ & $69(54.76)$ & $65(59.10)$ & $96(54.55)$ & \\
\hline Physical activity (\%) & & & & & 0.336 \\
\hline Heavy & $5(1.21)$ & $2(1.59)$ & $1(0.91)$ & $2(1.14)$ & \\
\hline Middle & $82(19.90)$ & $20(15.87)$ & $28(25.45)$ & $34(19.32)$ & \\
\hline Light & $325(78.89)$ & $104(82.54)$ & $81(73.64)$ & $140(79.54)$ & \\
\hline Daytime outdoor activity (\%) & & & & & 0.242 \\
\hline Never & $121(29.37)$ & $34(26.98)$ & $29(26.36)$ & $58(32.95)$ & \\
\hline$<1 \mathrm{~h} / \mathrm{d}$ & $85(20.63)$ & $30(23.81)$ & $22(20.00)$ & $33(18.75)$ & \\
\hline $1-3 \mathrm{~h} / \mathrm{d}$ & $188(45.63)$ & $54(42.86)$ & $54(49.09)$ & $80(45.45)$ & \\
\hline$>3 \mathrm{~h} / \mathrm{d}$ & $18(4.37)$ & $8(6.35)$ & $5(4.55)$ & $5(2.85)$ & \\
\hline Sunshine time (\%) & & & & & 0.625 \\
\hline$<1 \mathrm{~h} / \mathrm{d}$ & $262(63.59)$ & $81(64.29)$ & $70(63.64)$ & $111(63.07)$ & \\
\hline $1-2 \mathrm{~h} / \mathrm{d}$ & $133(32.28)$ & $40(31.74)$ & $38(34.54)$ & $55(31.25)$ & \\
\hline$>2 \mathrm{~h} / \mathrm{d}$ & $17(4.13)$ & $5(3.97)$ & $2(1.82)$ & $10(5.68)$ & \\
\hline
\end{tabular}

Values are presented as mean \pm SD or $n(\%)$.

ysis a $p$ value $<0.05$ based on two-sided test was considered statistically significant.

\section{RESULTS}

General characteristics of prediabetic patients by vitamin $D$ status

The characteristics of participants are summarized in Table 1. Overall, 96 men and 316 women were included in the analysis. The prevalence of a deficiency $(<20 \mathrm{ng} /$ $\mathrm{mL})$ or insufficiency $(20-30 \mathrm{ng} / \mathrm{mL})$ of vitamin $\mathrm{D}$ was $30.58 \%$ and $26.70 \%$, respectively. The proportion of subjects who had a serum $25(\mathrm{OH}) \mathrm{D}_{3}$ level $\geq 30 \mathrm{ng} /$ $\mathrm{mL}$ was $42.72 \%$. Generally, women with vitamin D deficiency or insufficiency were higher than the men $(p<0.05)$. There were no significant differences for age, drinking, smoking, physical activity, daytime outdoor activity and sunshine time among three groups $(p>0.05)$. The subject whose sunshine times less than $1 \mathrm{~h}$ per day was $63.59 \%$.

Metabolic characteristics of prediabetic patients by vitamin D status

The metabolic characteristics by serum $25(\mathrm{OH}) \mathrm{D}_{3}$ level are shown in Table 2. The BMI and WC in the vitamin D insufficient and deficient group were higher than those of the vitamin D sufficient group $(p<0.05)$. The SBP, DBP, TG, LDL-C, SUA and creatinine in the vitamin $\mathrm{D}$ deficient group were higher than those in the vitamin D sufficient group $(p<0.05)$. The HDL-C in the vitamin
D deficient group was lower than those in the vitamin D sufficient group $(p<0.05)$. However, there were no differences in TC and urea nitrogen among these three groups $(p>0.05)$.

Comparison of prevalence of metabolic risk factors in prediabetic patients by vitamin $D$ status

As shown in Table 3, the total prevalence of MS was $13.83 \%$. Compared with the vitamin D deficient group, the prevalence of MS, hyperglycemia and hypertension were higher than those in the vitamin $\mathrm{D}$ insufficient group or sufficient group $(p<0.05)$. The prevalence of central obesity in the vitamin $\mathrm{D}$ deficient group were higher than those in the vitamin D insufficient and vitamin D sufficient group, and the prevalence of central obesity in the vitamin D insufficient group was also higher than those in the vitamin D sufficient group $(p<0.05)$. Moreover, the prevalence of dyslipidemia in the vitamin D deficient group was higher than those in the vitamin D sufficient group $(p<0.05)$.

Linear regression analysis between serum $25(\mathrm{OH}) \mathrm{D}_{3}$ levels and MS risk factors

The association between serum $25(\mathrm{OH}) \mathrm{D}_{3}$ levels and MS risk factors was assessed using linear regression analysis (Table 4). Serum vitamin D levels were inversely associated with WC, SBP, DBP, TG and SUA $(p<0.05)$. Serum vitamin D levels were positively associated with HDL-C. After adjusting for potential confounders including age, sex and BMI, the inverse or positive association 
Table 2. Metabolic characteristics of prediabetic patients by vitamin D status.

\begin{tabular}{|c|c|c|c|c|c|}
\hline \multirow[b]{2}{*}{ Metabolic characteristics } & \multicolumn{4}{|c|}{ Vitamin D status } & \multirow[b]{2}{*}{$p$ value } \\
\hline & Total & $\begin{array}{c}\text { Vitamin D } \\
\text { deficiency } \\
(<20 \mathrm{ng} / \mathrm{mL})\end{array}$ & $\begin{array}{c}\text { Vitamin D } \\
\text { insufficiency } \\
(20 \text { to }<30 \mathrm{ng} / \mathrm{mL})\end{array}$ & $\begin{array}{c}\text { Vitamin D } \\
\text { sufficiency } \\
(\geq 30 \mathrm{ng} / \mathrm{mL})\end{array}$ & \\
\hline Number of subjects & 412 & 126 & 110 & 176 & \\
\hline Body mass index $\left(\mathrm{kg} / \mathrm{m}^{2}\right)$ & $24.23 \pm 3.44$ & $25.67 \pm 3.70$ & $24.52 \pm 3.44^{*}$ & $23.01 \pm 2.76^{* \#}$ & $<0.001$ \\
\hline Waist circumference $(\mathrm{cm})$ & $75.68 \pm 10.72$ & $79.93 \pm 10.72$ & $76.54 \pm 10.46^{*}$ & $72.10 \pm 9.74^{* \#}$ & $<0.001$ \\
\hline Systolic blood pressure (mmHg) & $118.14 \pm 15.90$ & $121.87 \pm 15.85$ & $118.05 \pm 17.08$ & $115.54 \pm 14.69^{*}$ & 0.003 \\
\hline Diastolic blood pressure (mmHg) & $77.27 \pm 9.67$ & $79.69 \pm 9.97$ & $77.59 \pm 9.76$ & $75.14 \pm 8.92^{*}$ & $<0.001$ \\
\hline Fasting plasma glucose $(\mathrm{mmol} / \mathrm{L})$ & $5.98 \pm 0.34$ & $6.11 \pm 0.35$ & $5.97 \pm 0.35^{*}$ & $5.89 \pm 0.30^{*}$ & $<0.001$ \\
\hline $\begin{array}{l}\text { High-density lipoprotein } \\
\text { cholesterol }(\mathrm{mmol} / \mathrm{L})\end{array}$ & $1.32 \pm 0.26$ & $1.26 \pm 0.24$ & $1.31 \pm 0.25$ & $1.36 \pm 0.27^{*}$ & 0.009 \\
\hline $\begin{array}{l}\text { Low-density lipoprotein } \\
\text { cholesterol }(\mathrm{mmol} / \mathrm{L})\end{array}$ & $3.16 \pm 0.77$ & $3.29 \pm 0.72$ & $3.18 \pm 0.81$ & $3.07 \pm 0.76^{*}$ & 0.048 \\
\hline Total cholesterol (mmol/L) & $5.20 \pm 0.91$ & $5.29 \pm 0.80$ & $5.23 \pm 1.04$ & $5.12 \pm 0.89$ & 0.233 \\
\hline Triglyceride $(\mathrm{mmol} / \mathrm{L})$ & $1.35 \pm 0.77$ & $1.54 \pm 0.94$ & $1.35 \pm 0.63$ & $1.21 \pm 0.70^{*}$ & 0.001 \\
\hline Serum uric acid $(\mu \mathrm{mol} / \mathrm{L})$ & $274.35 \pm 71.42$ & $298.07 \pm 75.41$ & $271.38 \pm 70.23^{*}$ & $259.23 \pm 64.84^{*}$ & $<0.001$ \\
\hline Urea nitrogen $(\mathrm{mmol} / \mathrm{L})$ & $4.44 \pm 1.08$ & $4.54 \pm 1.20$ & $4.48 \pm 1.06$ & $4.35 \pm 0.99$ & 0.272 \\
\hline Creatinine $(\mu \mathrm{mol} / \mathrm{L})$ & $57.95 \pm 11.41$ & $61.18 \pm 11.47$ & $56.35 \pm 11.44^{*}$ & $56.65 \pm 10.92^{*}$ & 0.001 \\
\hline
\end{tabular}

Values are presented as mean \pm SD.

* Compared with vitamin D deficiency, $p<0.05$;

\# Compared with vitamin D insufficiency, $p<0.05$.

Table 3. Comparison of prevalence of metabolic risk factors in prediabetic patients by vitamin D status.

\begin{tabular}{|c|c|c|c|c|c|}
\hline \multirow[b]{2}{*}{ Metabolic risk factors } & \multicolumn{4}{|c|}{ Vitamin D status } & \multirow[b]{2}{*}{$p$ value } \\
\hline & Total & $\begin{array}{c}\text { Vitamin D } \\
\text { deficiency } \\
(<20 \mathrm{ng} / \mathrm{mL})\end{array}$ & $\begin{array}{c}\text { Vitamin D } \\
\text { insufficiency } \\
(20 \text { to }<30 \mathrm{ng} / \mathrm{mL})\end{array}$ & $\begin{array}{c}\text { Vitamin D } \\
\text { sufficiency } \\
(\geq 30 \mathrm{ng} / \mathrm{mL})\end{array}$ & \\
\hline Number of subjects & 412 & 126 & 110 & 176 & \\
\hline Metabolic syndrome (\%) & $57(13.83)$ & $34(26.98)$ & $12(10.91)^{*}$ & $11(6.25)^{*}$ & $<0.001$ \\
\hline Central obesity (\%) & $144(34.95)$ & $70(55.56)$ & $40(36.36)^{*}$ & $34(19.32)^{* \#}$ & $<0.001$ \\
\hline Hyperglycemia (\%) & $120(29.13)$ & $64(50.79)$ & $28(25.45)^{*}$ & $28(15.91)^{*}$ & $<0.001$ \\
\hline Hypertension (\%) & $85(20.63)$ & $40(31.75)$ & $19(17.27)^{*}$ & $26(14.77)^{*}$ & 0.001 \\
\hline Dyslipidemia (\%) & $109(26.46)$ & $47(37.30)$ & $30(27.27)$ & $32(18.18)^{*}$ & 0.001 \\
\hline
\end{tabular}

Values are presented as $n(\%)$.

* Compared with vitamin D deficiency, $p<0.05$;

\# Compared with vitamin D insufficiency, $p<0.05$.

of serum vitamin D levels and MS risk factors (WC, TG, HDL-C and SUA) were still remained $(p<0.05)$.

\section{DISCUSSION}

In the present study, we observed that Chinese adults with PreDM were more likely to have low serum $25(\mathrm{OH})$ $\mathrm{D}_{3}$ levels. There was an inverse relationship between 25(OH) $\mathrm{D}_{3}$ levels and $\mathrm{WC}, \mathrm{TG}$, and SUA, and a positive relationship between $25(\mathrm{OH}) \mathrm{D}_{3}$ levels and HDL-C. It was demonstrated that a sufficient $25(\mathrm{OH}) \mathrm{D}_{3}$ level might have possible beneficial effects on metabolic risk factors in Chinese adults with PreDM.

Evidence from observational studies have pointed that the role of vitamin D status and metabolic risk factors with non-diabetic adults $(24,25)$ or patients with dia- betes (26), which was assistance with our study among Chinese adults with PreDM. However, the previous study did not find the association between a low serum vitamin D status and central obesity among prediabetic Korean adults (27). In the current study, a significant inverse association was found between serum $25(\mathrm{OH}) \mathrm{D}_{3}$ levels and central obesity. The inverse association between vitamin D levels and central obesity might be explained by the role of vitamin D in absorption of calcium. It has been shown that calcium intake and high levels of calcium are associated with lower adiposity (32). In addition, the elevated intact parathyroid hormone (iPTH) observed in subjects with low $25(\mathrm{OH}) \mathrm{D}_{3}$ levels might play a causal role in the pathogenesis of increased adiposity (33). 
Table 4. Linear regression coefficients between serum $25(\mathrm{OH}) \mathrm{D}_{3}$ level and metabolic risk factors in prediabetic patient.

\begin{tabular}{|c|c|c|c|c|c|c|}
\hline \multirow{2}{*}{ Metabolic risk factors } & \multicolumn{3}{|c|}{ Unadjusted } & \multicolumn{3}{|c|}{ Adjusted $^{1}$} \\
\hline & B (SE) & $\beta$ & $p$ value & B (SE) & $\beta$ & $p$ value \\
\hline Waist circumference $(\mathrm{cm})$ & $-0.633(0.106)$ & -0.283 & $<0.001$ & $-0.707(0.134)$ & -0.315 & $<0.001$ \\
\hline Systolic blood pressure ( mmHg) & $-0.179(0.074)$ & -0.118 & 0.016 & $-0.114(0.082)$ & -0.076 & 0.162 \\
\hline Diastolic blood pressure (mmHg) & $-0.358(0.121)$ & -0.144 & 0.003 & $-0.250(0.132)$ & -0.101 & 0.058 \\
\hline Triglyceride $(\mathrm{mmol} / \mathrm{L})$ & $-5.042(1.513)$ & -0.162 & 0.001 & $-4.172(1.595)$ & -0.134 & 0.009 \\
\hline $\begin{array}{l}\text { High-density lipoprotein } \\
\text { cholesterol (mmol/L) }\end{array}$ & $18.632(4.453)$ & 0.202 & $<0.001$ & $18.184(4.770)$ & 0.197 & $<0.001$ \\
\hline $\begin{array}{l}\text { Low-density lipoprotein } \\
\text { cholesterol }(\mathrm{mmol} / \mathrm{L})\end{array}$ & $-2.906(1.540)$ & -0.093 & 0.060 & $-2.403(1.630)$ & -0.077 & 0.141 \\
\hline Total cholesterol (mmol/L) & $-1.603(1.303)$ & -0.061 & 0.219 & $-1.323(1.419)$ & -0.050 & 0.352 \\
\hline Serum uric acid ( $\mu \mathrm{mol} / \mathrm{L})$ & $-0.073(0.016)$ & -0.218 & $<0.001$ & $-0.080(0.020)$ & -0.239 & $<0.001$ \\
\hline
\end{tabular}

${ }^{1}$ Adjusted for age, sex and BMI.

Similarly to our results, many studies have reported that patients with insufficient levels of vitamin D have high prevalence of dyslipidemia, they showed that the use of this vitamin might reduce levels of TG, TC, and might improve HDL-C level (34-37). Vitamin D is shown to exert a role in the transportation of cholesterol by regulating the apolipoprotein A-1 levels, and it may act in the reduction of LDL-C uptake, may decrease the formation of foam cells, and may enhance the production of HDL-C. The play of vitamin D as an antiinflammatory and on the reduction of oxidative stress also is important on the improvement of plasma lipids (38-41). In addition, sterol regulatory element-binding proteins (SREBPs) plays a crucial role in regulation the transcription and expression of lipid synthetic enzymes in the liver, which are associated with the lipogenesis of cholesterol, fatty acid, and TG. Recently, it was demonstrated that vitamin D metabolite (25-hydroxyvitamin D) impairs SREBP activation by inducing proteolytic processing and ubiquitin-mediated degradation of SREBP cleavage-activating protein (SCAP), thereby decreasing SREBP levels independently of the vitamin D receptor (42). The mechanism of vitamin D-mediated lipid control might be useful in the treatment of metabolic diseases.

Moreover, we have observed an inverse relationship between $25(\mathrm{OH}) \mathrm{D}_{3}$ levels and SUA among PreDM patients, which suggested that vitamin D might have benefit on hyperuricemia. As a predictor of MS, hyperuricemia has been long observed to occur with an increased frequency among population with high risks for MS and its components (43). Previous studies have shown a reverse association between vitamin D status and SUA in postmenopausal women (44), patients with diabetes (45), or stable renal failure (46). A number of animal and human studies have indicated that vitamin $\mathrm{D}$ and uric acid (UA) metabolism pathways were related (47-49). Findings in humans demonstrated a negative association between parathyroid hormone (PTH) and SUA $(48,49)$, which corresponded to findings from a study in postmenopausal women given teriparatide
(50). Vitamin D insufficiency could activate parathyroid to induce the release of PTH (51) which was considered to raise SUA level (48). Evidence from genomewide association studies (GWAS) have suggested that inherited characteristics played roles in UA and vitamin D metabolism pathways $(52,53)$. Most genes involved in excretion of UA via the urate transporters. The ATPbinding cassette subfamily $\mathrm{G}$ member 2 (ABCG2) loci was the strongest influence in Asian population (54). And the group-specific component (GC) at rs2282679 was also most significantly associated with serum vitamin D level in Asian population (55). Thakkinstian et al. assessed the birectional causal pathways of vitamin $\mathrm{D}$ and UA using a mediation analysis with accounting for GC and ABCG2 polymorphisms and the results suggested potential causal associations between the GC gene and UA through the vitamin $\mathrm{D}$ mediator, and the ABCG2 and the vitamin D through the UA mediator (56). Results from a meta-analysis (57) suggested that the highest levels of serum vitamin D were associated with a $43 \%$ reduction in cardiometabolic disorders. Therefore, the impact of vitamin D supplementation on hyperuricemia and consequently the influence of SUA lowering treatment on metabolic risk factors prevention are needed to be clarified.

Firstly due to the cross-sectional nature of study, we cannot confer a causal link between vitamin D status and metabolic risk factors. Secondly, despite several adjustments, further control for confounding variables such as other micronutrients deficiencies, seasonal variations and psychosocial factors will be needed to reach an independent association between vitamin D status and metabolic risk factors. Thirdly, we did not examine the dietary intake of vitamin D. Our results showed that there was no significant difference in sunshine time per day among the vitamin D sufficient group, vitamin D insufficient group and vitamin D deficient group, which suggested that it was possible that the dietary intake of vitamin D could influence the serum vitamin D status among vitamin D sufficient group, vitamin D insufficient group and vitamin D deficient group in PreDM patients. 
Further study will be performed to assess the relationship between the dietary vitamin D status and metabolic risk factors in PreDM patients. Finally, future prospective and intervention studies should be performed to demonstrate the causal effect of vitamin D on metabolic risk factors in PreDM patients.

\section{CONCLUSIONS}

Our results showed a remarkable prevalence of low levels of vitamin $\mathrm{D}$ in prediabetic patients and this deficiency is related to higher values for WC, TG, SUA and low levels of HDL-C. Therefore, the knowledge of the metabolic profile and levels of vitamin $\mathrm{D}$ in prediabetic patients with cardiovascular risk may be helpful in the development of an adequate therapeutic approach and modifications in the lifestyle that can prevent future complications and may improve the quality of life of these patients.

\section{Acknowledgments}

This research was supported by a grant from the National Natural Science Foundation of China (No. 81502809) and National Science and Technology Support Program (No. 2012BAI02B02). All the authors contributed to study conception and design, acquisition of data, analysis and interpretation of data, drafting of manuscript and critical revision.

\section{REFERENCES}

1) Yang W, Lu J, Weng J, Jia W, Ji L, Xiao J, Shan Z, Liu J, Tian H, Ji Q, Zhu D, Ge J, Lin L, Chen L, Guo X, Zhao Z, Li Q, Zhou Z, Shan G, He J. 2010. Prevalence of diabetes among men and women in China. N Engl J Med 362: 1090-1101.

2) Xu Y, Wang L, He J, Bi Y, Li M, Wang T, Wang L, Jiang Y, Dai M, Lu J, Xu M, Li Y, Hu N, Li J, Mi S, Chen CS, Li G, Mu Y, Zhao J, Kong L, Chen J, Lai S, Wang W, Zhao W, Ning G. 2013. Prevalence and control of diabetes in Chinese adults. JAMA 310: 948-959.

3) Cornier MA, Dabelea D, Hernandez TL, Lindstrom RC, Steig AJ, Stob NR, Van Pelt RE, Wang H, Eckel RH. 2008. The metabolic syndrome. Endocr Rev 29: 777-822.

4) Li Y, Zhao L, Yu D, Wang Z, Ding G. 2018. Metabolic syndrome prevalence and its risk factors among adults in China: A nationally representative cross-sectional study. PLoS One 13: e0199293.

5) Tuomilehto J, Lindström J, Eriksson JG, Valle TT, Hämäläinen H, Ilanne-Parikka P, Keinänen-Kiukaanniemi S, Laakso M, Louheranta A, Rastas M, Salminen V, Uusitupa M. 2001. Prevention of type 2 diabetes mellitus by changes in lifestyle among subjects with impaired glucose tolerance. N Engl J Med 344: 1343-1350.

6) Knowler WC, Barrett-Connor E, Fowler SE, Hamman RF, Lachin JM, Walker EA, Nathan DM. 2002. Reduction in the incidence of type 2 diabetes with lifestyle intervention or metformin. N Engl J Med 346: 393-403.

7) Kawahara T, Takahashi K, Inazu T, Arao T, Kawahara C, Tabata T, Moriyama H, Okada Y, Morita E, Tanaka Y. 2008. Reduced progression to type 2 diabetes from impaired glucose tolerance after a 2-day in-hospital diabetes educational program: the Joetsu Diabetes Prevention Trial. Diabetes Care 31: 1949-1954.

8) Kawamori R, Tajima N, Iwamoto Y, Kashiwagi A, Shi- mamoto K, Kaku K. 2009. Voglibose for prevention of type 2 diabetes mellitus: a randomised, double-blind trial in Japanese individuals with impaired glucose tolerance. Lancet 373: 1607-1614.

9) Holick MF, Chen TC. 2008. Vitamin D deficiency: a worldwide problem with health consequences. Am J Clin Nutr 87: 1080S-1086S.

10) Ning Z, Song S, Miao L, Zhang P, Wang X, Liu J, Hu Y, Xu Y, Zhao T, Liang Y, Wang Q, Liu L, Zhang J, Hu L, Huo M, Zhou Q. 2016. High prevalence of vitamin D deficiency in urban health checkup population. Clin Nutr 35: 859-863.

11) Song S, Zhou L, Si S, Liu J, Zhou J, Feng K, Wu J, Zhang W. 2013. The high prevalence of vitamin D deficiency and its related maternal factors in pregnant women in Beijing. PLoS One 8: e85081.

12) Lu HK, Zhang Z, Ke YH, He JW, Fu WZ, Zhang CQ, Zhang ZL. 2012. High prevalence of vitamin D insufficiency in China: relationship with the levels of parathyroid hormone and markers of bone turnover. PLoS One 7: e47264.

13) Fang F, Wei H, Wang K, Tan L, Zhang W, Ding L, Liu T, Shan Z, Zhu M. 2018. High prevalence of vitamin D deficiency and influencing factors among urban and rural residents in Tianjin, China. Arch Osteoporos 13: 64.

14) Liu J, Zhang W. 2015. The influence of the environment and clothing on human exposure to ultraviolet light. PLoS One 10: e0124758.

15) Reichel H, Koeffler HP, Norman AW. 1989. The role of the vitamin D endocrine system in health and disease. $N$ Engl J Med 320: 980-991.

16) Kienreich K, Grubler M, Tomaschitz A, Schmid J, Verheyen N, Rutters F, Dekker JM, Pilz S. 2013. Vitamin D, arterial hypertension \& cerebrovascular disease. Indian J Med Res 137: 669-679.

17) Pludowski P, Holick MF, Pilz S, Wagner CL, Hollis BW, Grant WB, Shoenfeld Y, Lerchbaum E, Llewellyn DJ, Kienreich K, Soni M. 2013. Vitamin D effects on musculoskeletal health, immunity, autoimmunity, cardiovascular disease, cancer, fertility, pregnancy, dementia and mortality-a review of recent evidence. Autoimmun Rev 12: 976-989.

18) Rejnmark L, Avenell A, Masud T, Anderson F, Meyer HE, Sanders KM, Salovaara K, Cooper C, Smith HE, Jacobs ET, Torgerson D, Jackson RD, Manson JE, Brixen K, Mosekilde L, Robbins JA, Francis RM, Abrahamsen B. 2012. Vitamin D with calcium reduces mortality: patient level pooled analysis of 70,528 patients from eight major vitamin D trials. J Clin Endocrinol Metab 97: 2670-2681.

19) Hilger J, Friedel A, Herr R, Rausch T, Roos F, Wahl DA, Pierroz DD, Weber P, Hoffmann K. 2014. A systematic review of vitamin D status in populations worldwide. $\mathrm{Br}$ J Nutr 111: 23-45.

20) Grundy SM. 2012. Prediabetes, metabolic syndrome, and cardiovascular risk. J Am Coll Cardiol 59: 635-643.

21) Orchard TJ, Temprosa M, Goldberg R, Haffner S, Ratner R, Marcovina S, Fowler S. 2005. The effect of metformin and intensive lifestyle intervention on the metabolic syndrome: the Diabetes Prevention Program randomized trial. Ann Intern Med 142: 611-619.

22) Abbasi F, Blasey C, Feldman D, Caulfield MP, Hantash FM, Reaven GM. 2015. Low circulating 25-hydroxyvitamin D concentrations are associated with defects in 
insulin action and insulin secretion in persons with prediabetes. J Nutr 145: 714-719.

23) Mansuri S, Badawi A, Kayaniyil S, Cole DE, Harris SB, Mamakeesick M, Maguire J, Zinman B, Connelly PW, Hanley AJ. 2015. Associations of circulating 25(OH)D with cardiometabolic disorders underlying type 2 diabetes mellitus in an Aboriginal Canadian community. Diabetes Res Clin Pract 109: 440-449.

24) Yin X, Sun Q, Zhang X, Lu Y, Sun C, Cui Y, Wang S. 2012. Serum 25(OH)D is inversely associated with metabolic syndrome risk profile among urban middle-aged Chinese population. Nutr J 11: 68 .

25) Kim S, Lim J, Kye S, Joung H. 2012. Association between vitamin D status and metabolic syndrome risk among Korean population: Based on the Korean National Health and Nutrition Examination Survey IV-2, 2008. Diabetes Res Clin Pract 96: 230-236.

26) Pan GT, Guo JF, Mei SL, Zhang MX, Hu ZY, Zhong CK, Zeng CY, Liu XH, Ma QH, Li BY, Qin LQ, Zhang ZL. 2016. Vitamin D deficiency in relation to the risk of metabolic syndrome in middle-aged and elderly patients with type 2 diabetes mellitus. J Nutr Sci Vitaminol 62: 213-219.

27) Kwon HN, Lim H. 2016. Relationship between serum vitamin D status and metabolic risk factors among Korean adults with prediabetes. PLoS One 11: $\mathrm{e} 0165324$.

28) Scragg R, Sowers M, Bell C. 2004. Serum 25-hydroxyvitamin D, diabetes, and ethnicity in the Third National Health and Nutrition Examination Survey. Diabetes Care 27: 2813-2818.

29) American Diabetes Association. 2012. Standards of medical care in diabetes-2012. Diabetes Care 35: S11-S63.

30) Holick MF. 2006. High prevalence of vitamin D inadequacy and implications for health. Mayo Clin Proc 81: 353-373.

31) Grundy SM, Cleeman JI, Daniels SR, Donato KA, Eckel RH, Franklin BA, Gordon DJ, Krauss RM, Savage PJ, Smith SC Jr, Spertus JA, Costa F, American Heart Association, National Heart, Lung, and Blood Institute. 2005. Diagnosis and management of the metabolic syndrome: an American Heart Association/National Heart, Lung, and Blood Institute Scientific Statement. Circulation 112: $2735-2752$.

32) Cunha KA, Magalhães EI, Loureiro LM, Sant'Ana LF, Ribeiro AQ, Novaes JF. 2015. Calcium intake, serum vitamin D and obesity in children: is there an association? Rev Paul Pediatr 33: 222-229.

33) Parikh SJ, Edelman M, Uwaifo GI, Freedman RJ, SemegaJanneh M, Reynolds J, Yanovski JA. 2004. The relationship between obesity and serum 1,25-dihydroxy vitamin D concentrations in healthy adults. J Clin Endocrinol Metab 9: 1196-1199.

34) Rolim MC, Santos BM, Conceição G, Rocha PN. 2016. Relationship between vitamin D status, glycemic control and cardiovascular risk factors in Brazilians with type 2 diabetes mellitus. Diabetol Metab Syndr 8: 77.

35) Canguven O, Talib RA, El Ansari W, Yassin DJ, AI Naimi A. 2017. Vitamin D treatment improves levels of sexual hormones, metabolic parameters and erectile function in middle-aged vitamin D deficient men. Aging Male 20: $9-16$.

36) Nada AM, Shaheen DA. 2017. Cholecalciferol improves glycemic control in type 2 diabetic patients: a 6-month prospective interventional study. Ther Clin Risk Manage
13: $813-820$.

37) Lupton JR, Faridi KF, Martin SS, Sharma S, Kulkarni K, Jones SR, Michos ED. 2016. Deficient serum 25-hydroxyvitamin D is associated with an atherogenic lipid profile: the very large database of lipids (VLDL-3) study. J Clin Lipidol 10: 72-81.

38) Mousa A, Naderpoor N, de Courten MPJ, Scragg R, de Courten B. 2017. 25-Hydroxyvitamin D is associated with adiposity and cardiometabolic risk factors in a predominantly vitamin D-deficient and overweight/obese but otherwise healthy cohort. J Steroid Biochem Mol Biol 173: 258-264.

39) Baz-Hecht M, Goldfine AB. 2010. The impact of vitamin D deficiency on diabetes and cardiovascular risk. Curr Opin Endocrinol Diabetes Obes 17: 113-119.

40) Al-Daghri NM, Alkharfy KM, Al-Saleh Y, Al-Attas OS, Alokail MS, Al-Othman A, Moharram O, El-Kholie E, Sabico S, Kumar S, Chrousos GP. 2012. Modest reversal of metabolic syndrome manifestations with vitamin D status correction: a 12-month prospective study. Metabolism 61: 661-666.

41) Oh J, Weng S, Felton SK, Bhandare S, Riek A, Butler B, Proctor BM, Petty M, Chen Z, Schechtman KB, Bernal-Mizrachi L, Bernal-Mizrachi C. 2009. 1,25(OH $)_{2}$ vitamin D inhibits foam cell formation and suppresses macrophage cholesterol uptake in patients with type 2 diabetes mellitus. Circulation 120: 687-698.

42) Asano L, Watanabe M, Ryoden Y, Usuda K, Yamaguchi T, Khambu B, Takashima M, Sato SI, Sakai J, Nagasawa K, Uesugi M. 2017. Vitamin D metabolite, 25-hydroxyvitamin D, regulates lipid metabolism by inducing degradation of SREBP/SCAP. Cell Chem Biol 24: 207-217.

43) Wen CP, David Cheng TY, Chan HT, Tsai MK, Chung WS, Tsai SP, Wahlqvist ML, Yang YC, Wu SB, Chiang PH, Wen SF. 2010. Is high serum uric acid a risk marker or a target for treatment? Examination of its independent effect in a large cohort with low cardiovascular risk. Am J Kidney Dis 56: 273-288.

44) Peng H, Li H, Li C, Chao X, Zhang Q, Zhang Y. 2013. Association between vitamin D insufficiency and elevated serum uric acid among middle-aged and elderly Chinese Han women. PLoS One 8: e61159.

45) Yilmaz H, Kaya M, Sahin M, Delibasi T. 2012. Is vitamin D status a predictor glycaemic regulation and cardiac complication in type 2 diabetes mellitus patients? Diabetes Metab Syndr 6: 28-31.

46) Vanholder R, Patel S, Hsu CH. 1993. Effect of uric acid on plasma levels of $1,25(\mathrm{OH})_{2} \mathrm{D}$ in renal failure. J Am Soc Nephrol 4: 1035-1038.

47) Chen W, Roncal-Jimenez C, Lanaspa M, Gerard S, Chonchol M, Johnson RJ, Jalal D. 2014. Uric acid suppresses 1 alpha hydroxylase in vitro and in vivo. Metabolism 63: 150-160.

48) Hui JY, Choi JW, Mount DB, Zhu Y, Zhang Y, Choi HK. 2012. The independent association between parathyroid hormone levels and hyperuricemia: a national population study. Arthritis Res Ther 14: R56.

49) Dalbeth N, Horne A, Gamble GD, Ames R, Mason B, McQueen FM, Bolland MJ, Grey A, Reid IR. 2009. The effect of calcium supplementation on serum urate: analysis of a randomized controlled trial. Rheumatology (Oxford) 48: 195-197.

50) Miller PD, Schwartz EN, Chen P, Misurski DA, Krege JH. 2007. Teriparatide in postmenopausal women with osteoporosis and mild or moderate renal impairment. 
Osteoporos Int 18: 59-68.

51) Emilion E, Emilion R. 2011. Estimation of the 25(OH) vitamin D threshold below which secondary hyperparathyroidism may occur among African migrant women in Paris. Int J Vitam Nutr Res 81: 218-224.

52) Nath SD, Voruganti VS, Arar NH, Thameem F, LopezAlvarenga JC, Bauer R, Blangero J, MacCluer JW, Comuzzie AG, Abboud HE. 2007. Genome scan for determinants of serum uric acid variability. J Am Soc Nephrol 18: 3156-3163.

53) Yang Q, Guo CY, Cupples LA, Levy D, Wilson PW, Fox CS. 2005. Genome-wide search for genes affecting serum uric acid levels: the Framingham Heart Study. Metabolism 54: 1435-1441.

54) Yang $B$, Mo Z, Wu C, Yang H, Yang $X$, He Y, Gui L, Zhou L, Guo H, Zhang X, Yuan J, Dai X, Li J, Qiu G, Huang S, Deng Q, Feng Y, Guan L, Hu D, Zhang X, Wang T, Zhu J,
Min X, Lang M, Li D, Hu FB, Lin D, Wu T, He M. 2014. A genome-wide association study identifies common variants influencing serum uric acid concentrations in a Chinese population. BMC Med Genomics 7: 10.

55) Zhang Z, He JW, Fu WZ, Zhang CQ, Zhang ZL. 2013. An analysis of the association between the vitamin D pathway and serum 25-hydroxyvitamin D levels in a healthy Chinese population. J Bone Miner Res 28: 1784-1792.

56) Thakkinstian A, Anothaisintawee T, Chailurkit L, Ratanachaiwong W, Yamwong S, Sritara P, Ongphiphadhanakul B. 2015. Potential causal associations between vitamin $\mathrm{D}$ and uric acid: Bidirectional mediation analysis. Sci Rep 5: 14528.

57) Parker J, Hashmi O, Dutton D, Mavrodaris A, Stranges S, Kandala NB, Clarke A, Franco OH. 2010. Levels of vitamin D and cardiometabolic disorders: Systematic review and meta-analysis. Maturitas 65: 225-236. 